\title{
IRONIA I NOSTALGIA. O TWÓRCZOŚCI MICHAŁA WITKOWSKIEGO
}

\author{
AGNIESZKA CZYŻAK ${ }^{1}$ \\ (Uniwersytet im. Adama Mickiewicza w Poznaniu)
}

Słowa kluczowe: ironia, nostalgia, PRL, Michał Witkowski

Key words: irony, nostalgia, People's Republic of Poland, Michał Witkowski

\begin{abstract}
Abstrakt: Agnieszka Czyżak, IRONIA I NOSTALGIA. O TWÓRCZOŚCI MICHAŁA WITKOWSKIEGO. „PORÓWNANIA” 13, 2013, t. XIII, s. 117-125. ISSN 1733-165X. Artykuł stanowi próbę zarysowania głównych problemów prozy Michała Witkowskiego. Pisarz często wracał w swoich powieściach do historii PRL-u, jako kraju rządzonego w latach 1944-89 przez komunistów, zależnego od ZSRR. Poddawał analizie doświadczenia przeszłości na swój odrębny sposób. Jego narracje, jak i innych członków najmłodszego pokolenia twórców, potwierdzały powszechne przekonanie, że przeszłość powinna zostać przedstawiona na nowo, bowiem PRL wciąż wydaje się niedostatecznie opisany w ramach wspólnotowego, czy nawet narodowego dyskursu. Różnice stworzonej przez Witkowskiego wizji ostatnich dekad wynikają także, a może przede wszystkim, z wypracowanych przez niego sposobów używania ironii i nostalgii - rozłącznie i w specyficznym połączeniu. Sukces rozwiązań Witkowskiego zależy od jego krytycznego nastawienia wobec ideologicznych, a przede wszystkim społecznych pewników, jak i zdolności rozpoznania kluczowych problemów, np. stereotypów zbiorowych oraz towarzyszących im materialnych uwarunkowań - ich powszechny i przemożny wpływ niezmiennie oddziaływał na (świadome, a częściej nieświadome) wybory i decyzje ludzi z minionej epoki.
\end{abstract}

Abstract: Agnieszka Czyżak, IRONY AND NOSTALGY. ON MICHAŁ WITKOWSKI'S LITERARY OUTPUT. "PORÓWNANIA" 13, 2013, Vol. XIII, p. 117-125. ISSN 173-165X. The article is an attempt at sketching the main problems ofMichał Wikowski's prose. In his novels, the author often returned to the history of People's Republic of Poland (PRL), as a country governed in 1944-1989 by the Communist authorities, dependent on the USSR. He analysed the experiences of the past in his own way. His narratives, as well as those of other members of the youngest generation of writers, confirmed the common belief that the past should be described in a different manner, because PRL still seems to be an incomplete object of common or even national

\footnotetext{
${ }^{1}$ Correspondence Address: agnieszkaczy@tlen.pl
} 
discourse. Differences of Witkowski's vision of the last decades result also, or possibly to a larger extent, from his method of using irony and nostalgia - both separately and in a particular conjuction. The success of Witkowski's attempts depends on the critical awareness of ideological and especially social assumptions, as well as on the ability to identify the crucial questions, i.e. the mental stances and their material conditions, whose common and totalising character strongly influenced (consciously or, more often, subconsciously) choices or decisions of the people living then and there.

PRL bywał wielokrotnie określany „światem nie przedstawionym”, często zdawał się też światem „nieprzedstawialnym” - niemożliwym do zamknięcia w ramach tekstu literackiego. Lidia Burska pisząc niedawno o wyrastającym z najgłębszych potrzeb, ale niezwykle naiwnym, życzeniowym, jak się okazało po latach, projekcie "nowych” zadań literatury stworzonych przez Adama Zagajewskiego i Juliana Kornhausera², przekonywała nawet:

Wielka opowieść w roli podpowiadacza okazała się mistyfikacją, zachęcała do odkrywania głębi i prawdy, które nie istniały [...] Powieść realistyczna wywiązała się ze swych obowiązków: opisała, co napotkała na gościńcu życia i uprzejmie powstrzymała się od głoszenia prawd, których nie znalazła. Dzięki temu wyszło na jaw, że ich nie ma³

Przekonanie, iż rzeczywistość PRL-u pozostaje nadal sferą koniecznych eksploracji i zasadnych powrotów podziela wielu badaczy. Robert Ostaszewski, krytyk związany z pokoleniem tzw. „roczników siedemdziesiątych”, upatrywał nawet $\mathrm{w}$ podjęciu tego tematu szansy dla młodych twórców, przede wszystkim na większą niezależność i wyrazistość. Zdaniem Ostaszewskiego:

Dać ją może [...] zwrócenie się ku opisowi doświadczeń lat osiemdziesiątych [...] poszukiwanie formuły tekstowej pozwalającej na uporanie się z doświadczeniami ostatnich dziesięcioleci, formuły w miarę nowoczesnej, nie reprodukującej bogoojczyźnianego banału, stanowić może ciekawe wyzwanie dla pisarza ${ }^{4}$.

2 A. Zagajewski, J. Kornhauser, Świat nie przedstawiony. Kraków 1974.

${ }^{3}$ L. Burska, Realizm i socjalizm. W: PRL - świat (nie)przedstawiony. Red. A. Czyżak, J. Galant i M. Jaworski. Poznań 2010, s. 125. Burska dopowiada, analizując literacką próbę sprostania założeniom zawartym w Świecie nie przedstawionym, zawartą w utworze Zagajewskiego Ciepło, zimno: „Cóż odkrył Zagajewski? Zamiast «nowego typu bohatera», nowej świadomości - repliki filisterstwa, konformistyczne społeczeństwo i mieszczucha Oremusa, gładko wchodzącego w gotowe role, schematy zachowań, wzorce kariery itp."

${ }^{4}$ R. Ostaszewski, Dzieci gorszej koniunktury. „Fa-art” 2000, nr 3-4, s. 81. Krytyk pisząc o tekstach powstałych jeszcze w dziewiątej dekadzie - takich jak Raport o stanie wojennym Marka Nowakowskiego czy Kraj świata Janusza Andermana - stwierdził jednoznacznie: „u schyłku PRL powstało całkiem 
Propozycja ta jest $\mathrm{w}$ istocie projektem zastosowania podwojonego dystansu wobec minionych realiów - kreowanie literackich wizji byłoby bowiem powrotem do doświadczeń z dzieciństwa, a lata siedemdziesiąte i osiemdziesiąte stać by się musiały zarazem czasoprzestrzenią i odtwarzaną z pamięci, i oglądaną z perspektywy dziecka.

Twórczość Michała Witkowskiego, prozaika urodzonego w połowie lat siedemdziesiątych, jest specyficznym wypełnieniem takiego projektu. Przestrzenie PRL-u są w jego prozie stałym punktem odniesienia dla opowieści o czasach transformacji, często przywoływanym tłem wydarzeń współczesnych, kontrapunktowo traktowaną sferą znaczeń. Dzisiejsze zainteresowanie przestrzenią, jak przekonuje Elżbieta Rybicka w artykule Geopoetyka, geokrytyka, geokulturologia. Analiza porównawcza pojęć, dowodzą:

odejścia od myślenia o przestrzeni jako kategorii abstrakcyjnej w stronę miejsca i konkretnych lokalizacji - w konsekwencji kultura i wiedza zawsze są już usytuowane przestrzennie, a zarazem postrzegane i badane $\mathrm{z}$ konkretnego (jakkolwiek nie zawsze stałego) punktu widzenia [...] dowodzi też $\mathrm{w}$ równej mierze intencji przekraczania granic (dyscyplin, dziedzin sztuki) i poszukiwania nowych połączeń ${ }^{5}$.

Witkowski, i odtwarzając z pamięci konkretne doświadczenia dzieciństwa, i kreując losy swoich zmyślonych bohaterów, zdaje się zawsze dążyć do ukonkretnienia przestrzeni, w której rozgrywają się powieściowe wydarzenia - to z reguły wyraźnie wskazywane geograficznie, realnie istniejące miejsca, w ściśle określonym czasie. $W$ jego utworach rozpoznawalne pejzaże, obrazy miast i letniskowych miejscowości, tworzą tło dla szczególnej gry równie rozpoznawalnymi konwencjami, schematami i wzorcami, także tymi przynależącymi do kultury popularnej. Przemysław Czapliński, analizując sytuację współczesnej literatury jako „nieobliczalnej przetwórni śmieci", tak określał jej funkcjonowanie:

na wejściu mamy śmieci ideologiczno-medialne, które udają pierwszorzędny towar, na wyjściu - bałagan, który jest niespójnością indywidualną. Z tego bałaganu może się zrodzić rozpacz albo przemoc, głębsza samoświadomość albo fanatyzm, ale każda $\mathrm{z}$ tych form będzie już miała za sobą próbę prywatyzacji. $W$ tym sensie tekst literacki to demonstracja jednostkowej nie/zdolności do przerabiania wspólnych śmieci na indywidualną narrację.

Taką wyraziście indywidualną narracją okazało się Lubiewo, "ciotowska księga”, opowieść o „wymierającym gatunku” przegiętych ciot, homoseksualistów

sporo takich tekstów, tylko tyle, że kilkanaście lat po ich publikacji są one «martwe»; czytelnicy już raczej po nie nie sięgną."

${ }^{5}$ E. Rybicka, Geopoetyka, geokrytyka, geokulturologia. Analiza porównawcza pojęć. „Białostockie Studia Literaturoznawcze" 2011, nr 2, s. 27-28.

${ }^{6}$ P. Czapliński, Tekst drugi. „Teksty Drugie” 2010, nr 1-2, s. 38. 
bytujących na obrzeżach oficjalnego życia Polski Ludowej. Zbigniew Jarzębowski w zwięzłym wyliczeniu podsumowywał ich powieściowy obraz:

akceptują swój status quo, z nostalgią wspominają czasy przedemancypacyjnego pedalstwa PRL-u, radzieckie koszary, siermiężną (acz jurną) lumpenproletariackość kolejowych nasypów, zapuszczonych parków, cuchnących piwnic [...] wydają się autentyczni $\mathrm{w}$ owym uporczywym trwaniu wbrew upływającemu czasowi, społecznocywilizacyjnym przemianom, przy całej mizerii egzystencji ${ }^{7}$.

Jarzębowski podkreślał także: „Ani literacki, ani popkulturowy, medialny, ani tym bardziej ów wyemancypowany, społecznie (i językowo) zlokalizowany, oswojony wizerunek geja im nie odpowiada" 8 .

Tęsknota za utraconymi przestrzeniami jest bowiem dla bohaterów (i narratora) Lubiewa tęsknotą za światem autentycznych doznań, nawet jeśli jest to dążność do samoponiżania, dążność do „zdobycia luja” za wszelką cenę, dążność do przekraczania wszelkich norm. Czas transformacji staje się tym samym dla nich czasem utraty własnych, wciąż od nowa zawłaszczanych, przestrzeni. Tymczasem opustoszałe koszary niszczeją, a w miejsce ukochanego parku bohaterowie „dostają" od nowej epoki galerię handlową. I są zmuszeni bezradnie przyglądać się zmianom, pozwalając sobie jedynie na narzekanie: „Cóż, cóż ja, dziadówka, poradzę? Z kijem na Wielki Kapitał? Torebką po głowie? I co ja im powiem, że to jest miejsce pamiątkowe?"9.

Jednocześnie bohaterowie - cioty, są pozbawieni poczucia wstydu, buntowniczo, a nawet anarchistycznie podważają swoją przynależność do wspólnoty, unieważniają obowiązek uczestnictwa w zbiorowych powinnościach, odmawiają przyjęcia narodowej tożsamości. Korzystając z wszelkich sprzyjających ich działaniom okoliczności, nie są skłonni do podejmowania roli ofiar - systemu, Historii, czy społeczeństwa. Tym samym wyraźniej podkreślają swoją odmienność i niezależność, a jednocześnie paradoksalnie i wręcz perwersyjnie wpisują się w - wykluczające kategorię wstydu - polskie narracje.

O (nie)obecności opowieści o wstydzie w narracji polskiego losu pisała Hanna Gosk, wskazując wówczas również na sferę złożonej z wielu wariantów potencjalnej narracji współodpowiedzialności za własną kondycję podporządkowanego, w której skład wejść powinny: „nie tylko opowieści o dostosowywaniu się do - w zróżnicowanym zakresie wynaturzonych - warunków bytowania [...] ale i o tym, jak z tej kondycji nauczono się czerpać korzyści, naturalizować ją, a nawet uważać za dobrą"10. Szczególnym wariantem opowieści o rzeczonej współ-

${ }^{7}$ Z. Jarzębowski, „piszę tę ciotowską księgę...". „Pogranicza” 2005, nr 1, s. 19.

8 Ibidem.

${ }^{9}$ M. Witkowski, Lubiewo. Kraków 2005, s. 14.

${ }^{10} \mathrm{H}$. Gosk, (Nie)obecność narracji o wstydzie w narracji losu polskiego. W: Kultura po przejściach, osoby z przeszłością. Polski dyskurs postzależnościowy - konteksty i perspektywy badawcze. Red R. Nycz. Kraków 2011, s. 87. 
odpowiedzialności są opowiadania Witkowskiego zamieszczone w zbiorze Fototapeta.

Teksty przesycone ironią i autoironią są powrotem do realiów lat osiemdziesiątych, wiwisekcją dokonywaną na dorosłych przez czujnie obserwujące ich dziecko, które nawet potrafi przyjąć na siebie ciężar winy za wielekroć dostrzegane, zbytnie dopasowywanie się do warunków schyłkowego PRL-u. Opowiadanie zatytułowane jednoznacznie Kolaboracja przywołuje okoliczności wyjazdu do Związku Radzieckiego. Historia wycieczki wygranej w jednym z konkursów organizowanych przez Telewizję Polską rozpoczyna się od pewnego niedzielnego przedpołudnia. Wtedy to, po ogłoszeniu w Teleranku konkursu dla dzieci na opowieść o życiu radzieckich pionierów, ojciec nastoletniego bohatera-narratora zamyka się na dłuższy czas $\mathrm{w}$ gabinecie a potem, jak wspomina po latach potomek: "daje mi gotowy tekst do przepisania: przepisz, synku kulfonami wzorowego pierwszaka, pojedziemy razem do dzieci do Leningradu".

Zwycięstwo Michała zostaje wkrótce ogłoszone i w Teleranku, i lokalnej prasie - jednak o wyjazd trzeba starać się dodatkowo, a nawet dotrzeć z prośbą o dotrzymanie obietnicy do gmachu na Woronicza. W końcu bohater z ojcem zostają dokooptowani do jednej z organizowanych regularnie przez Towarzystwo Przyjaźni Polsko Radzieckiej wycieczek do Kijowa, traktowanych przez uczestników jako podróż handlowa. Sekwencję zdarzeń podsumowuje autoironiczna konkluzja, ukazana jako samoświadomość i trzynastoletniego, i trzydziestoletniego adepta sztuki pisarskiej: ,już wtedy jako pisarz Michaił Stanisławowicz był skłonny do wszelkiego rodzaju zdrady, podlizywania się i czerpania zysków"11.

Opowiadanie pt. Mosina jest z kolei zapisem wizyt młodocianego bohatera w małej, podpoznańskiej miejscowości, w domu mieszkającej tam od wielu lat babci. Babcia okazuje się istotą przede wszystkim doskonale przystosowaną do zmieniających się, lecz zawsze uciążliwych warunków powojennego życia - wnuk jest świadkiem jej doskonale opanowanej umiejętności prowadzenia handlu wymiennego wymuszonego przez realia lat osiemdziesiątych. W Mosinie dni upływały dziecku wedle stałych schematów, porządek tygodnia również zdawał się nie podlegać żadnym zmianom. Wszystkie elementy prowincjonalnej rzeczywistości PRL-u ulegały swoistemu skondensowaniu w niedzielę. $W$ dniu świątecznym bowiem stawały się:

sto razy bardziej nudne, małomiasteczkowe, smutne i banalne [...] Wszystkie te rytuały, krochmalenia, wędzenia, smażenia, kąpiele, fryzjerzy, sprzątania, poprawiania się będą miały na dnie niewypowiedziane pytanie: dla kogo to, na co, po co taki splendor, skoro i tak nikt nie widzi, nikt tego życia w niszy nie obserwuje? [...] wstawiam kwiaty do wazonu i wyję po cichu: na co? ${ }^{12}$.

\footnotetext{
${ }^{11}$ M. Witkowski, Fototapeta. Warszawa 2006, s. 35-36.

12 Ibidem, s. 130.
} 
Prowincjonalna Mosina zdaje się symbolizować wszystkie małe miasteczka Polski Ludowej - to przestrzeń wegetatywnego trwania istot niezdolnych nawet wyobrazić sobie innej egzystencji.

Z kolei w powieści Barbara Radziwiłłówna z Jaworzna-Szczakowej Witkowski poddał artystycznej wiwisekcji region z pozoru całkowicie odmienny, tętniący jakoby życiem i pracą, gęsto zaludniony Śląsk, z tego samego czasu rozkładu systemu i początków transformacji. Krzysztof Uniłowski jednak tak interpretował wykreowaną w utworze czasoprzestrzeń:

Apokalipsa czai się za progiem: zwiastuje ją grożąca kosmiczna katastrofą kometa, ewokują wszechobecne błoto, „zimowa zgniłka”, padający bez końca deszcz albo śnieg przemieszany z pyłem węglowym. Krótko mówiąc wszechobecny „bród, smród, nędza i nuda" [...] postindustrialny Śląsk jest miejscem w stanie postępującej dematerializacji13.

Przestrzeń istniejąca realnie jako gospodarcza ruina, a symbolicznie jako „kraina spustoszenia”, funkcjonuje w utworze - zdaniem Uniłowskiego - jako „hiperrealna alegoria nowoczesnej gospodarki", demaskująca jej wynaturzenia i podatność na zniszczenie. Narratorem opowieści jest właściciel lombardu - pan Hubert, skądinąd „władca dyskursów”, tak przeszłości, jak i teraźniejszości, który od początku starał się $\mathrm{w}$ tak wielorako zdegradowanej i naznaczonej rozpadem przestrzeni, nie tyle zrobić karierę, ile znaleźć bezpieczną życiową przystań.

Bohater snuje niespiesznie swą autobiograficzną opowieść, która stanowi specyficzne przetworzenie przełomowych doświadczeń historycznych. Bartosz Dąbrowski analizując „psychotyczną mowę bohatera" stwierdził:

Hybrydyzacja i mimikra stanowią w powieści Witkowskiego zasadę naczelną konstruowania wielokształtnej morfologii podmiotu zainfekowanego przez prawie wszystkie zbiorowe tożsamości. Ostatecznie jednak także ta groteskowa "terapia szokowa" nie pociąga za sobą terapeutycznego efektu ozdrowienia, gdyż kolonialna postzależność wyklucza skuteczną subwersję ${ }^{14}$.

Gawęda szlachecka przemieszana z wszelkimi językami współczesności, operująca szeroką gamą stylistycznych rejestrów nie burzy stereotypowych ujęć przeszłości, lecz je - ironicznie, a zarazem paradoksalnie - zatrzymuje w przestrzeni zbiorowych mitów, a tym samym - utrwala.

${ }^{13} \mathrm{~K}$. Uniłowski, „Exodus non est?" proza polska między postkomunizmem i postmodernizmem. W: PRL świat (nie) przedstawiony..., op. cit., s. 321.

${ }^{14}$ B. Dąbrowski, Mimikra, vintage, ironia i gorzkie znaczenie. Gombrowicz, Dehnel, Witkowski i postkolonialne ciagi dalsze. W: (P)o zaborach, (p)o wojnie, (p)o PRL. Polski dyskurs postzależnościowy dawniej i dziś, Red. H. Gosk i E. Kraskowska. Kraków 2013, s. 494. Badacz zamyka swoje rozważania stwierdzeniem, iż narrator „konstruuje powieściowy kosmos na gombrowiczowską modłę, tak jakby innego wyjścia poza psychozą z postzależnościowego impasu nie było". 
Umiejący dostosowywać się do zmiennych warunków, zawsze płynący z prądem pan Hubert, spędzając dnie $\mathrm{w}$ przestrzeni zapełnionej tandetnymi, zdezelowanymi przedmiotami, zaczyna zdawać sobie sprawę, iż prowadzi: „zakład permanentnej denominacji, inflacji", na klientów zaś patrzy nie tylko z lekceważeniem, ale i współczuciem: „Przynosili te swoje wzruszające śmieci, ale dostawali za nie jeszcze mniej, jakieś grosze, a za te grosze potem w melinie jeszcze mniej, niż były warte. Zaledwie kroplę wódki na ich spieczone usta"15. Stosy zbędnych rzeczy, (wśród których bardzo rzadko trafić można na coś wartościowego) przypominają o marności życia, ucieleśniają jego znikomość, a jednocześnie stanowią dowód, iż przełom niczego nie zmienił, a śladem transformacji pozostaje jedynie zalew tandety nowego sortu.

Proza Witkowskiego jest zresztą pełna starego i nowego „badziewia”, przedmiotów naznaczonych bylejakością, brzydotą i czającym się w nich od początku rozpadem. Świat tandety, ten ucieleśniający współczesne tandetne marzenia o życiowym sukcesie (choć nie oferującym ich spełnienia), jak przekonuje Jerzy Jarzębski, stał się dziś niezwykle często podejmowanym tematem:

"pałubiasta niezgrabność" badziewia budzi na powrót erotyczny dreszcz - w kontekście literatury, szczególnie dzisiejszej, tak czułej na los wykluczonych i wydziedziczonych z materialnego awansu. Literatura w dzisiejszej Polsce obfituje w podobne Stasiukowemu przykłady zafascynowania śmieciowym towarem i otaczającą go subkulturą ${ }^{16}$.

Jarzębski podkreśla, iż „«Badziewie» odtwarza jedynie pieszczoną w wyobraźni powierzchnię świata sukcesu - jego substancja pozostaje niedostępna"17. Podobną funkcję pełnią tabloidy, kolorowa prasa kobieca czy plotkarskie portale.

Witkowski w innej swojej powieści, zatytułowanej Margot przekonuje natomiast, iż „świat sukcesu" w ogóle nie istnieje, nie ma bowiem bytu substancjalnego, lecz wyłącznie medialny. Zaludniające utwór postacie, takie jak wiodąca podwójne życie tirówka Margot, cudownie uzdrowiona święta Asia czy robiący oszałamiającą karierę Waldek Mandarynka (pobudzany do walki w świecie show biznesu pastą przeznaczoną do końskich kopyt), to nawet nie bohaterowie literaccy, a medialne wiadomości, internetowe ciekawostki, tabloidowe skandale.

Swoistym podsumowaniem wcześniejszych rozpoznań Witkowskiego stał się utwór autotematyczny i autoironiczny zarazem - powieść „kryminalna” pt. Drwal. Jest $\mathrm{w}$ niej i przestrzeń skomplikowanych relacji między ciotami i lujami, romanse rozgrywające się $\mathrm{w}$ nadmorskiej scenerii, jest opowieść o meandrach powstawania

${ }^{15}$ M. Witkowski, Barbara Radziwiłtówna z Jaworzna-Szczakowej. Warszawa 2007, s. 43.

${ }^{16}$ J. Jarzębski, Antyfetysze. W: Fantazmaty i fetysze w literaturze polskiej XX (i XXI) wieku. Red. J. Wierzejska, T. Wójcik i A. Zieniewicz. Warszawa 2011, s. 30. Badacz obok Michała Witkowskiego, wśród zafascynowanych tandetą pisarzy wymienia Dorotę Masłowską, Michała Olszewskiego, Sylwię Chutnik.

17 Ibidem, s. 30. 
związanych z czasem transformacji przestępczych lub półlegalnych imperiów, a nawet medialna sfera literackiej kariery. Bohater, zbliżający się do czterdziestki pisarz, wyrusza po sezonie do Międzyzdrojów, by napisać „kryminał albo lepiej powieść dla młodzieży". Wszystko, co mu się przydarza, traktuje jako doświadczenie "przydatne do prozy", a motywacją tworzenia jest spodziewana, a uzyskana właśnie dzięki niej popularność w określonych kręgach czytelników. Pisarz mówi wprost: "tu by trzeba napisać coś dla chłopców, żeby były pościgi, dużo o motocyklach, odkrycie skarbu i w ogóle Pan Samochodzik. Żeby gówniarzerii trochę przyszło"18.

Jednak napisanie powieści sensacyjnej czy powieści dla młodzieży okazuje się niemożliwe - $\mathrm{w}$ ich konwencję wpisana jest bowiem wiara $\mathrm{w}$ porządek świata, przekonanie narratora, iż taki porządek można odtworzyć $\mathrm{w}$ tekście i uzgodnić z nim przebieg zdarzeń ${ }^{19}$. W świecie przedstawionym Witkowskiego nie istnieje nawet pozór takiego porządku, narracja pozbawia złudzeń, że można wykreować świat tekstowy wedle dawnych porządków. Powstająca ostatecznie powieść nazwana, z braku lepszego określenia, obyczajową - zawiera polifoniczny zestaw zużytych języków, nieprzydatnych konwencji, dekonstruowanych wzorców. Narracja stanowi mocno zindywidualizowane przetworzenie nie tylko wspólnych odpadów pozostałych po cywilizacyjnym krachu, ale i okruchów własnych bardzo specyficznych doświadczeń. Zbudowana jest także ze szczątków tego, co staje się coraz bardziej niczyje - składników kultury popularnej PRL-u, coraz szybciej wypychanych poza obręb wspólnotowej pamięci.

Wielokształtny i zmienny narrator-bohater to równocześnie magister z Wrocławia, pisarz z Warszawy, celebryta, „mąż Jacykowa”. Przybywa na prowincję z przekonaniem o własnej kulturowej wyższości i dzieli spotkanych ludzi na miejscowych, obciążonych dziedzictwem wszelakich cywilizacyjnych zapóźnien, i przyjezdnych, wnoszących $\mathrm{w}$ małomiasteczkową przestrzeń powiew innego (lepszego) świata. Poszukiwanie partnera przypomina tym samym polowanie przedstawiciel wyższej kultury łowi wśród wałęsających się bez celu lub wystających na przystankach autobusowych „młodych lujów” nieświadomą siebie i swej przyszłości ofiarę.

Wybór miejsca akcji ma natomiast wymiar symboliczny. Międzyzdroje po sezonie odsłaniają swą prawdziwą naturę - tandetną tymczasowość, retuszowany

18 M. Witkowski, Drwal. Warszawa 2011, s. 257.

${ }_{19}$ Pisarz zna, oczywiście, przepis na powieść, która zostałaby doceniona przez krytyków i czytelników. Przedstawia nawet jej treatment - to tragiczna, lecz zmieniająca się w farsę opowieść z czasów II wojny światowej, o miłości, która połączyła córkę gestapowca i żydowskiego skrzypka. Bohater przeżywa wyobrażony, ale, jak twierdzi, pewny sukces: „Za tę książkę dostaję wszystkie nagrody, Kościelskich i Nike, ale nie jadę jej odebrać, gdyż Warszawa to gniazdo os. Tu muszą dziennikarze przyjechać. Komórka dzwoni non stop [...] Luj dłubie w nosie i bierze udział w sesji zdjęciowej ze mną do „Wysokich Obcasów”, pt. Razem przez siedem strumieni.” (Drwal, s. 213-214) 
z wysiłkiem, choć wciąż nieprawdziwy urok, oszukańczy blichtr, spełzający z każdym kolejnym deszczem. Stary ośrodek dla partyjnych działaczy zmieni się być może w kierowane przez Szwedów spa, być może, wyrosną kolejne hotele nie zmieni to jednak $\mathrm{w}$ realny $\mathrm{i}$ trwały sposób przestrzeni naznaczonej piętnem rozpadu, poddanej erozji, podatnej na zniszczenie. Powierzchowne zmiany, jakim podlegać będzie przestrzeń, nie uchroni mieszkańców przed wyrokiem - tak, jak wcześniej, „za PRL-u” skazani zostali jedynie na wegetację, ciułanie marnych groszy, wystawanie bez celu na przystankach i snucie marzeń, o innym lepszym świecie. Przełom okazuje się pozorem, transformacja - ułudą, a tym, co stałe, pozostaje mizeria polskiej kondycji.

Przestrzeń marnej egzystencji, czy w Polsce Ludowej, czy w III Rzeczpospolitej, jest ukazywana przez Witkowskiego z zawsze wyrazistą, choć zmienną w natężeniu ironią, natomiast oglądowi zabarwionemu nostalgią poddana zostaje dawna, utracona ostatecznie literatura - jako sfera zdolna wytwarzać lub odtwarzać sensy, cząstkowe choćby porządki czy szczątki hierarchii wartości. Witkowski wpisuje się w ponowoczesne postrzeganie kulturowego (nie)porządku. Posługując się metaforą przestrzenną Patrycja Cembrzyńska w swojej książce pt. Wieża Babel, stworzyła wizję współczesnego powrotu do zachwianej, poddanej zwątpieniu, niepewnej jutra utopii. Zdaniem badaczki, po porażce emancypacyjnego przedsięwzięcia nowoczesności ponowoczesność:

znów wznosi wieżę, znów buduje utopię, lecz tym razem ta budowa pomyślana zostaje jako na zawsze niezrealizowany plan. Założone z góry niedokończenie projektu, jego ciągła rewizja (czy ktoś powie - permanentna dekonstrukcja), która polegałaby na podtrzymywaniu otwarcia na "obcy głos”, każdorazowe uruchamianie „armii metafor", okazują się ratunkiem dla wspólnoty, pozostającej wspólnotą rozstajnych dróg, wciąż czekającą i gotową ugościć każdego wędrowca, świadomą tego, że dopiero jego przybycie ją ukonstytuuje ${ }^{20}$.

Proza Witkowskiego zdaje się spełnianiem, choć może jedynie symulowaniem spełniania, takiego projektu ponowoczesności w mikroskali jednostkowych zmagań $\mathrm{w}$ sferze literackich (i nieliterackich, czyli medialno-performatywnych) prób konstytuowania narracji, które staną się istotne, lub choćby zauważalne w obszarze przekształcającej się nieustannie wspólnotowej komunikacji. Tworząc swe powieści, nigdy nieograniczane do prezentowania jedynie słusznej racji, czy określanej jako jedynie słuszna wizji przyszłości, nie tylko kreuje nowe przestrzenie "otwarcia na obcy głos", ale niestrudzenie nakłania, prowokuje czy wręcz zmusza do uznania, iż należy je nieustannie poszerzać.

${ }^{20}$ P. Cembrzyńska, Wieża Babel. Nowoczesny projekt porzadkowania świata i jego dekonstrukcja. Kraków 2012, s. 18. 
